\title{
ע Kestävää kehitystä ja terveyttä edistävä ravitsemus- ja ruokapolitiikka
}

Ruokavaliolla on keskeinen merkitys terveyden edistämisessä ja ilmastonmuutoksen torjunnassa. Kestäryys ja terveellisyys ovat osa kansallisia ja pohjoismaisia ravitsemussuosituksia mutta ne toteutuvat puutteellisesti. Ongelmina on nykyään esimerkiksi liiallinen energian ja punaisen lihan kulutus ja liian vähäinen kasvisten, hedelmien ja marjojen käyttö. Ravitsemus- ja ruokapolitiikassa tulisi nykyistä selvemmin huomioida ihmisen terveyden ja ruokajärjestelmän lisäksi myös ympäristö ja maapallon kantokyvyn rajat. Kestävää ja terveellistä ruokavaliota voi edistää vaikuttamalla maatalouspolitiilkkaan sekä hyödyntämällä fiskaalisia keinoja, ruokapalveluja ja julkisia hankintoja, koulutusta ja informaatiota, tutkimusta ja tuotekehitystä sekä vaikuttamalla ruokaympäristöön. Ruokajärjestelmän muutos kohti kestävää ja terveellistä ruokavaliota vaatii monia erilaisia poikkihallinnollisia toimia. Mukaan tulee saada hallituksen lisäksi kunnat, joilla on vastuu monista käytännön ratkaisuista liittyen esimerkiksi ruokaympäristöön, julkisten ruokapalvelujen tarjontaan ja opetuksen järjestämiseen.

\section{ASIASANAT: ravitsemus, kestävyys, ilmastonmuutos, politiikka, kansanterveys} SIRPA SARLIO

\section{YDINASIAT}

- Ravitsemussuositusten mukainen ruokavalio edistää sekä terveyttä että kestävyyttä.

- Ruokapolitiikassa tulee huomioida sekä terveellisyys että ilmastomuutoksen torjunta.

- Ruokajärjestelmän muutos kohti kestävää kehitystä vaatii monia poikkihallinnollisia toimia.

\section{JOHDANTO}

Ruoan tuotannolla on merkittäviä sosiaalisia, taloudellisia ja terveydellisiä vaikutuksia, mutta se on myös tärkein yksittäinen elinympäristöämme muokkaava tekijä. Kansainvälisen ilmastopaneelin arvion mukaan noin $25-30 \%$ kasvihuonekaasupäästöistä syntyy ruokajärjestelmässä (1). Tässä artikkelissa keskitytään kestävää kehitystä ja terveyttä edistävään ravitsemus- ja ruokapolitiikkaan erityisesti ilmastonmuutoksen näkökulmasta, mutta kestävyyden muitakin ulottuvuuksia on mukana. Se, mitä lautaselle laitamme, vaikuttaa merkittävästi terveyden ja kasvihuonepäästöjen lisäksi myös muun muassa vesijalanjälkeen, vesistöjen rehevöitymiseen, kemikaalikuormaan, maankäyttöön ja luonnon monimuotoisuuteen. Radikaaleja ja mittavia muutoksia nykyiseen ruokajärjestelmään tarvitaan, jotta maapallon tulevaisuus ja ihmisten terveys voidaan turvata kestävällä tavalla (2,3). Tämä artikkeli pohjautuu osin vuonna 2018 julkaistuun kirjaan (3) täydennettynä erityisesti esimerkeillä Suomen ruoka- ja ravitsemuspolitiikasta.

Kestävä kehitys ja erityisesti ilmastonmuutos ovat viime vuosina nousseet esiin myös Suomen ruoka- ja ravitsemuspolitiikassa. Kansallisten ravitsemussuositusten laadinnan yhteydessä on arvioitu, että ruoan tuotannon ja kulutuksen ketju pellolta pöytään aiheuttaa noin kolmanneksen Suomen koko tuotannon ja kulutuksen ympäristövaikutuksista. Pohjoismaisiin ravitsemussuosituksiin pohjautuvissa kansallisissa ravit- 
Taulukko 1. Eri elintarvikkeiden keskimääräisiä hiilijalanjälkiä

\begin{tabular}{|c|c|c|c|c|}
\hline & $\begin{array}{l}\text { Matala } \\
\text { alle } 1 \mathrm{CO}_{2} \text { eq } / \mathrm{kg}\end{array}$ & $\begin{array}{l}\text { Keskimääräinen } \\
1-4 \mathrm{CO}_{2} \text { eq/kg }\end{array}$ & $\begin{array}{l}\text { Korkea } \\
4-15 \mathrm{CO}_{2} \text { eq } / \mathrm{kg}\end{array}$ & $\begin{array}{l}\text { Hyvin korkea } \\
\text { yli } 15 \mathrm{CO}_{2} \mathrm{eq} / \mathrm{kg}\end{array}$ \\
\hline $\begin{array}{l}\text { Eläinperäiset } \\
\text { tuotteet }\end{array}$ & & $\begin{array}{l}\text { Suuri osa kaloista, } \\
\text { kananmuna, maito, } \\
\text { jukurtti hunaja, } \\
\text { hyönteiset }\end{array}$ & $\begin{array}{l}\text { Sianliha, broileri, } \\
\text { makkara, juusto, } \\
\text { katkaravut, voi, } \\
\text { simpukat, kerma, } \\
\text { taimen, mustekala, }\end{array}$ & $\begin{array}{l}\text { naudanliha, } \\
\text { lammas, } \\
\text { hummeri, } \\
\text { meriantura }\end{array}$ \\
\hline $\begin{array}{l}\text { Kasvikset, } \\
\text { hedelmät, } \\
\text { marjat, pähkinät }\end{array}$ & $\begin{array}{l}\text { avomaakasvikset, } \\
\text { useimmat tuoreet } \\
\text { hedelmät (ml. } \\
\text { omenat, } \\
\text { sitrushedelmät, } \\
\text { banaanit) marjat }\end{array}$ & $\begin{array}{l}\text { palkokasvit, } \\
\text { pähkinät, kuivatut } \\
\text { hedelmät, viljellyt } \\
\text { sienet, avokadot, } \\
\text { parsa, kasvihuone- } \\
\text { kasvikset }\end{array}$ & & \\
\hline Viljatuotteet & $\begin{array}{l}\text { Jauhot ja } \\
\text { jalostamaton vilja } \\
\text { (vehnä, ruis, } \\
\text { kaura), leipä }\end{array}$ & $\begin{array}{l}\text { Riisi, kvinoa, pasta, } \\
\text { aamiaismurot }\end{array}$ & & \\
\hline Sekalaista & $\begin{array}{l}\text { vesi, sokeri, tee, } \\
\text { kahvi, } \\
\text { kasvipohjaiset } \\
\text { maidonkorvikkeet } \\
\text { (soija- ja } \\
\text { mantelimaito) }\end{array}$ & $\begin{array}{l}\text { Hillot, suklaa, } \\
\text { kasviöljyt, tofu, } \\
\text { margariini, viini, } \\
\text { yrtit, mausteet }\end{array}$ & & \\
\hline
\end{tabular}

semussuosituksissa on jo vuodesta 2014 ollut mukana suositukset kestävistä ruokavalinnoista. Ilmastonmuutokseen vaikuttaminen hiilijalanjälkeä pienentämällä on mukana ravitsemussuosituksissa, mutta niissä on huomioitu myös muun muassa vesistöjen rehevöitymisen vähentäminen, luonnon monimuotoisuuden parantaminen sekä arvioitu osin myös ruokavalintojen sosiaalisia ja taloudellisia vaikutuksia (4). Ravitsemussuositusten noudattamisen tärkeys on Suomessa nostettu esiin myös vuonna 2014 hyväksytyssä maatalouden ilmasto-ohjelmassa (5) sekä vuonna 2017 hyväksytyssä Ruokapoliittisessa selonteossa (6).

Ravitsemussuosituksissa terveys- ja ympäristönäkökulmien yhdistäminen korostaa nykyistä runsaampaa kasvikunnan tuotteiden käyttöä ja eläinperäisten tuotteiden, erityisesti punaisen lihan käytön, vähentämistä. Kalojen kohdalla suositellaan luonnonkaloja, rasvojen kohdalla voin vaihtamista margariiniin ja rypsiöljyyn, riisin tilalle täysjyväohraa ja perunaa, soijan tilalle kotimaisia palkokasveja. Pullotettujen vesien tilalla suositellaan vesijohtovettä (4). Yksittäisten elintarvikkeiden hiilijalanjäljet voivat vaihdella suuresti tuotantotavoista ja olosuhteista riippuen. Keskimääräisiä arvioita erityyppisten elintarvikkeiden tuottamasta hiilijalanjäljestä perustuen katsauksiin elintarvikkeiden hiilijalanjäljestä (3,7-9) on koottuna taulukossa 1.

\section{SUOSITUKSET TERVEELLISESTÄ JA KESTÄVÄSTÄ RUOKAVALIOSTA EIVÄT TOTEUDU}

Terveellisen ja kestävän ruokavalion noudattaminen toteutuu Suomessa puutteellisesti. Viimeisimmän vuonna 2017 toteutetun Finravinto -tutkimuksen mukaan punaisen ja prosessoidun lihan kansallinen käyttösuositus, enintään $500 \mathrm{~g}$ viikossa, ylittyi $79 \%$ :lla miehistä ja $26 \%$ :lla naisista. Kasvisten, hedelmien ja marjojen syöntisuositus, vähintään 500g päivässä, alittui $86 \%$ :lla miehistä ja 78\%:lla naisista. Tyydyttyneiden rasvahappojen saantisuositus, korkeintaan 10\% kokonaisenergiasta, ylittyi 97\%:lla miehistä ja 96\%:lla naisista. Suurin osa tyydyttyneistä rasvahapoista tuli eläinperäisistä tuotteista (10).

Ruokavalion laadun lisäksi ongelmana on se, että saamme ruokavaliosta liikaa energiaa kulutukseen nähden. Työikäisen väestön lihavuus on Suomessa viimeisen kuuden vuoden aikana yleistynyt. Vain noin $28 \%$ yli 30 vuotiaista miehistä ja $37 \%$ naisista on normaalipainoisia. Ylimääräiset kilot lisäävät monien kansansairauksien, muun muassa diabeteksen, sepelvaltiotaudin, kihdin, sappikivien, astman sekä polvi- ja lonkkanivelrikon riskiä (11). Lihavuus on ongelma myös kestävyyden kannalta, koska väestön lihominen lisää ruoan kulutusta ja energian tarvetta. Kestävyyden kannalta kaikki ruoan ylikulutus on ympäristöä kuormittavaa (3). 
Nykyiset kansalliset ruoankäyttösuositukset terveellisen ja kestävän ruokavalion edistämisestä (4) toteutuvat siis huonosti. Vielä ongelmallisemmalta tilanne näyttää, jos suomalaisten ruoankäyttöä verrataan kansainvälisiin suosituksiin, joissa erityisesti punaisen lihan käyttöä esitetään rajoitettavaksi vielä merkittävästi tiukemmin kuin nykyisissä suosituksissamme. Terveellistä ja kestävää ruokavaliota analysoineen poikkitieteellisen asiantuntijaryhmän, ns. EAT-Lancet komission, globaali suositus esittää punaisen lihan maksimääräksi $98 \mathrm{~g}$ viikossa (2), joka on alle viidesosa nykyisestä suosituksesta (4) ja murtoosa nykykulutuksesta (10). Tilanne on hyvin samanlainen myös muissa pohjoismaissa, vaikka kestävyys on osa yhteisiä ravitsemussuosituksia ja pohjoismaita on pidetty pioneereina kestävän kehityksen edistämisessä. Esimerkiksi ruokavaliomme kasvihuonekaasupäästöt ylittävät tavoitetasot noin kolminkertaisesti (12).

Vaikuttavampia toimia tarvitaan, jotta ruokavaliota saadaan muokattua kestävämpään suuntaan. Tätä korostaa myös 3.6.2019 julkistettu hallitusohjelma, jossa ilmastoystävällinen ruokapolitiikka sekä ilmasto- ja ympäristöystävällinen ruokajärjestelmä on nostettu hallituksen tavoitteiksi. Hallitusohjelmassa luvataan muun muassa laatia kansallinen ilmastoruoka-ohjelma sekä strategia taloudellisesti, sosiaalisesti ja ekologisesti kestävästä ruokajärjestelmästä vuoteen 2030 mennessä (13).

\section{KESTÄVYYDEN JA TERVEYDEN EDISTÄMINEN}

Terveys ja ympäristönäkökulmien yhdistäminen on mahdollista. Ruokavalion muuttuminen nykyisten ravitsemussuositusten mukaiseksi vähentäisi jo sinällään ruoan ympäristövaikutusta $(4,12)$. Ruokaminimi -hankkeen laskelmien mukaan erityisesti lihan käytön rajoittamisella saadaan Suomessa lisähyötyjä. Pelkkiä kasvikunnan tuotteita sisältävällä vegaaniruokavaliolla kasvihuonekaasupäästöt vähenisivät noin $40 \%$. Merkittävä päästöjen vähennys saadaan myös kalakasvisvoittoisella ruokavaliolla, jossa juustojen sijaan nautitaan muita maitotuotteita. Ilmastoystävällisen ja ravitsemussuositusten mukaisen ruokavalion voi koostaa monella eri tavalla mutta keskimääräistä lihankulutusta pitäisi kuitenkin selvästi vähentää. (14)

Kestävän ja terveellisen ruokavalion edistäminen edellyttää poikkihallinnollista ja moni- tieteellistä lähestymistapaa. Se edellyttää myös politiikkatoimia, joissa huomioidaan tasavertaisesti ihmiset, ruokajärjestelmä ja ympäristö (ks. kuvio 1). Kaikki kolme ovat keskeinen osa ihmiskunnan ja maapallon kestävää tulevaisuutta. Ruokajärjestelmän tuottaman ruoan tulee täyttää ihmisten ravitsemukselliset tarpeet niin, että ruokavalio on turvallinen ja ylläpitää hyvinvointia ja terveyttä, mutta huomioi myös maapallon kantokyvyn. Jos ihmisten ravitsemuksellisia tarpeita ei huomioida niin ruoka voi lisätä virheravitsemusta. Ihmisten ravitsemus- ja terveystarpeiden lisäksi sosiaalinen ja kulttuurinen hyväksyttävyys on tärkeää. Jos ruoka ei ole sosiaalisesti ja kulttuurisesti hyväksyttävää niin se jää syömättä mikä voi lisätä ruokahävikin määrää. Ravitsemustarpeet voisi tyydyttää syömällä esimerkiksi hyönteisiä, tiettyjä leviä tai lemmikkikoiria mutta tämä ei olisi helposti kulttuurissamme hyväksyttävää. Mikäli maapallon rajoja taas ei kunnioiteta niin ruokavalio voi olla yksilön kannalta terveellinen, mutta tuhoaa elämän edellytyksiä pitkällä aikavälillä. Esimerkiksi kasvihuonekaasupäästöjen ja luonnon monimuotoisuuden häviämisen suhteen riskit maapallon kantokyvyn rajojen ylittämisestä ovat merkittävät, ja meidän tulisi siirtää kulutusta monipuolisempaan kasvisvoittoiseen ruokavalikoimaan. Ruokajärjestelmän toimivuuden turvaaminen on tärkeää koko ihmiskunnalle. Tähän liittyy läheisesti myös ruokaturva ja globaali sosiaalinen oikeudenmukaisuus. Globaali ruokajärjestelmä pystyy tällä hetkellä tuottamaan riittävästi ruokaa kaikille, mutta ruoka jakautuu hyvin epätasaisesti. Noin 800 miljoona ihmistä on aliravittuja, lähes 2 miljardia aikuista on ylipainoisia ja arviolta kolmasosa kulutukseen tarkoitetusta ruoasta päätyy ruokahävikkiin. (3)

Kestävää ja terveellistä ruokavaliota voi edistää monella tavalla kuten esimerkiksi vaikuttamalla maatalouspolitiikkaan sekä hyödyntämällä fiskaalisia keinoja, ruokapalveluita ja julkisia hankintoja, koulutusta ja informaatiota, tutkimusta ja tuotekehitystä sekä vaikuttamalla ruokaympäristöön tuuppauksen ja vastaavien keinojen avulla. Tutkimustietoa terveellisen ruokavalion tai kestävyyden edistämisestä on julkaistu paljon. Toisaalta tutkimuksia, jossa yhdistetään sekä terveellisen että kestävän ruokavalion edistäminen ravitsemus- ja ruokapolitiikan keinoin on toistaiseksi vähän. Alla on esimerkkejä mah- 


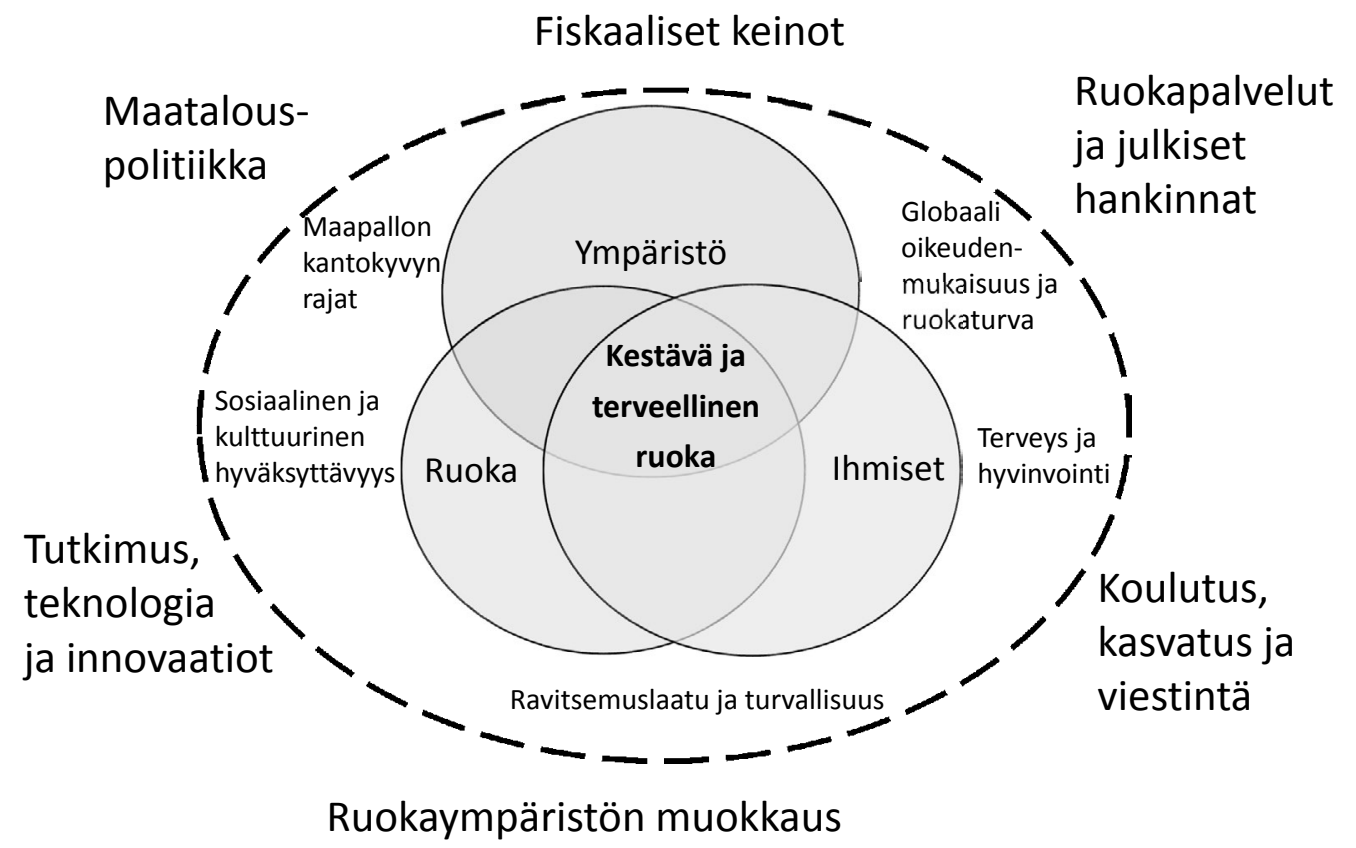

dollisista lähestymistavoista, joita on identifioitu tutkimuskirjallisuuden ja erilaisten politiikkadokumenttien analyysin avulla.

\section{MAATALOUSPOLITIIKKA}

EU:n maatalouspolitiikka ja maataloustuet ovat merkittävä ruoan tuotantoon vaikuttava tekijä, jossa ympäristönäkökulmat ovat viime vuosina vahvistuneet mutta terveydellä on ollut vain marginaalinen merkitytys. Yli puolet maataloustuista on käytännössä käytetty eläinperäisten (liha, maito) tuotteiden tuotannon tukemiseen. Kasvisten ja hedelmien tuotanto on ollut laskusuunnassa (15). Mikäli väestön terveyttä halutaan parantaa ja ilmastonmuutosta hillitä, tulisi tuotantoa pitkäjänteisesti ohjata terveyttä ja kestävyyttä edistävään suuntaan. Aikaisemmat toimet kuten Suomen kansallinen ilmasto-ohjelma (5) tai EU:n kouluhedelmäohjelma ovat olleet askel tähän suuntaan, mutta vahvempia toimia tuotannon rakenteen muuttamiseksi tarvitaan, mikäli halutaan edistää ravitsemussuositusten mukaista kestävää ruokavaliota.

Mahdollinen rakennemuutos tulee olemaan haasteellinen EU:ssa ja kaikissa pohjoismaissa (12). Meijeriteollisuus ja lihanjalostus ovat Suo- messa elintarviketeollisuuden kaksi suurinta toimialaa. Ne vastaavat $47 \%$ suomalaisen maatalouden markkinahintaisesta tuotosta vuonna 2017. Kotieläintalouden tarpeisiin käytetään nykyään yli 70\% maatalouden kokonaispinta-alasta. Siirtyminen ilmastohyötyjä tuottavaan kasvisvoittoiseen ruokavalioon mullistaisi Suomen maa- ja elintarviketalouden. Vaikka tuotannon arvo voisi säilyä nykytasolla niin muutos edellyttää merkittäviä investointeja kasviperäisten tuotteiden tuotantoon ja uusia arvoketjuja. Vaarana on myös sosiaaliset ja taloudelliset ongelmat kotieläintuotantoon keskittyneillä alueilla (14), joskin on arvioitu, että muutos voisi myös hyödyttää pientilallisia (12). Hallituksen tulevassa ilmasto-ruokaohjelmassa ja ilmastokestävän ruokajärjestelmän toimintasuunnitelmassa (13) voisi ilmastojalanjäljen pienentämisen lisäksi huomioida laaja-alaisesti nämä rakennemuutoksen sosiaaliset ja taloudelliset haasteet. Vaikutusarviointien systemaattinen käyttö on yksi työväline muutoksen toteuttamisessa ja päätöksenteossa. Taloudellisten vaikutusten lisäksi ruokavaliomuutosten ympäristö- ja terveysvaikutusten arviointi on keskeistä (16). 


\section{TUTKIMUS, TEKNOLOGIA JA INNOVAATIOT}

Muutos kohti ilmastoystävällistä ruokajärjestelmää vaatii tietopohjaa ja osaamisen vahvistamista. Tutkimusta tarvitaan koko ruokaketjussa tuotantopanoksista jalostukseen ja kuluttajan kauppakassista hävikin hallintaan. Sekä kansainvälisiä että kansallisia monitieteellisiä ja poikkihallinnollisia asiantuntijaryhmiä on ehdotettu tukemaan ruokajärjestelmän muutosta (2). Tutkimuksen, teknologian, innovaatioiden ja osaamisen tärkeyttä on nostettu esiin kansallisissa ohjelmissa $(5,6)$. Resurssejakin on viime vuosina kohdennettu ilmastoystävällisen ruokajärjestelmän kehittämiseen muun muassa osana valtioneuvoston selvitys- ja tutkimustoimintaa ja Suomen Akatemian strategista tutkimusta. Strategisen tutkimusneuvoston päätös 20.6.2019 rahoittaa tutkimusta kohti kestävää terveellistä ja ilmastoneutraalia ruokajärjestelmää yli 14 miljoonalla eurolla vuosina 2019-2022 on uusin kansallinen panostus aiheen tutkimukseen.

Elintarvikealan yritykset voivat edistää ilmastoystävällistä ruokavaliota myös kehittämällä tuotteita tukemaan kuluttajien ilmastoystävällisiä valintoja. Lihaa ja maitoa korvaavien kasviperäisten tuotteiden kysyntä on tasaisessa kasvussa, mikä on omiaan stimuloimaan tuotekehitystä. Esimerkiksi lihaa korvaavien tuotteiden markkinat kasvavat noin $14 \%$ vuosivauhtia. Tuotteita käyttävät myös muut kuin kasvissyöjät. Korvaavien tuotteiden käyttäjistä jo noin 90\% on sekaruokavaliota syöviä. Palkokasvien viljely on EU:ssakin kasvanut, joskin edelleen pääosa proteiinipitoisista kasveista päätyy rehukäyttöön (17). Tuotekehityksen tueksi on ehdotettu muun muassa kansallista tutkimus- ja kehitysohjelmaa, joka tukisi elintarviketeollisuuden muutosta kohti vähähiilisyyttä ja kiertotaloutta, käytännössä tukemalla innovaatioita ennen niiden kaupallistamista (14).

\section{RUOKAPALVELUT JA JULKISET HANKINNAT}

Ruokapalvelut ovat Suomessa olleet pitkään merkittävässä roolissa terveellisen syömisen tukemisessa. Kaikille koululaisille on tarjolla täysipainoinen ja ohjattu ateria. Lisäksi ilmaista tai tuettua ruokaa tarjotaan muun muassa päiväkodeissa, korkeakouluissa, armeijassa, työpaikoilla ja ikääntyneiden asumispalveluissa. Ruokapalvelujen tarjoamien aterioiden ravitsemuslaadusta on Suomessa olemassa ateriakohtaiset laatukri- teerit ja lisäksi ravitsemussuosituksissa on ohjeita kestävyyttä edistäviin valintoihin (4).

Kriteereitä ilmastoystävällisistä valinnoista ei toistaiseksi ole olemassa. Valtioneuvosto on tosin antanut 2016 periaatepäätöksen julkisten elintarvike- ja ruokapalveluhankintojen arviointiperusteista, mutta ilmastovaikutuksia huomioidaan periaatepäätöksessä (18) sekä sen pohjalta annetussa hankintaoppaassa (19) varsin suppeasti, lähinnä energiankäyttönä kasvikunnan tuotteissa ja leivässä sekä palmuöljytuotannon ongelmina. Periaatepäätöksen myötä jatkettiin luomu- ja lähiruokaohjelmia, joiden mahdolliset hyödyt liittyvät muualle kun ilmastonmuutoksen torjuntaan tai terveyden edistämiseen.

Hankintakriteereitä on myös monissa muissa maissa. Esimerkiksi EU:ssa on kestäviin hankintoihin tähtäävää ns. "Green Public Procurement" ohjeistusta. Ohjeistusta hyödynnetään EU:n jäsenmaissa kuitenkin hyvin vaihtelevasti eikä se nykyisellään sisällä ruoan ravitsemukselliseen laatuun liittyviä kriteereitä (20). Tutkimusten mukaan terveyden edistämiseen tähtäävillä hankintakriteereillä voisi edistää terveellisemmän ruoan tarjontaa ja muun muassa vähentää suolan, rasvan ja sokerin saantia (21).

Suomessa noin kolmasosa väestöstä syö päivittäin ruokapalvelujen valmistamia aterioita. Nämä tarjoavat erinomaisen mahdollisuuden sekä terveellisen että ympäristöystävällisen ruokailun edistämiseen. Jatkossa olisi hyödyllistä laatia sitovat ravitsemuslaatu- ja vähähiilisyystavoitteet julkisille ruokapalveluille (10).

\section{FISKAALISET KEINOT}

Tuotteiden hinta on merkittävä ostopäätökseen vaikuttava tekijä, joten taloudellisilla ohjauskeinoilla kuten tukijärjestelmillä ja verotuksella voidaan ohjata kulutusta haluttuun suuntaan. Haitallisten tuotteiden verotusta voidaan taloustieteen näkökulmasta perustella myös sillä, että niistä aiheutuvat ongelmat lisäävät yhteiskunnan kuluja, joten ylimääräisen veron sisällyttäminen tuotteen hintaan on perusteltua (2).

Mallinnukset liittyen tiettyjen elintarvikkeiden kuten punaisen lihan ja virvoitusjuomien sekä yleisemmin hiilidioksidipäästöjen verotuksesta viittaavat siihen, että fiskaalisista toimista olisi ilmasto- ja terveyshyötyjä (3). Esimerkiksi Springmann ym. (22) on arvioinut, että hiilidioksipäästöihin pohjautuva globaali elintarvikevero 
voisi vähentää kasvihuonepäästöjä noin $8,6 \%$ ja samalla vältettäisiin noin 510000 ennenaikaista kuolemaa. Vaikutus kuitenkin vaihtelisi alueittain ollen suurin kehittyneissä maissa. Hyötyjen määrää voisi kasvattaa ohjaamalla osa veron tulosta suositeltavien tuotteiden kuten hedelmien ja kasvisten tukemiseen (22). Näyttö on toistaiseksi kuitenkin niukkaa ja mahdolliset haittaverot tulisi suunnitella huolellisesti huomioiden erityisesti väestöryhmät, joiden tulotaso on matala (2).

Kestävä kehitys ja terveyden edistäminen verotuksella on nostettu osaksi hallitusohjelmaa. Terveyden edistäminen verotuksella kattaa virvotusjuomaveron korotuksen kohdentaen sen erityisesti sokeripitoisiin juomiin ja selvityksen mahdollisesta kansanterveyttä edistävästä verosta. Kestävän kehityksen verouudistus kattaa päästöihin pohjautuvan kulutusveron, jossa kehitetään myös elintarvikkeiden elinkaaripäästöjen arviointia kulutusverotuksen suuntaamiseksi ilmasto- ja ympäristövaikutukset huomioivaksi (13). Tuore selvitys (23) viittaa siihen, että hyvin suunniteltu fiskaalinen ohjaus on yhteiskunnallisesti kannattavaa. Vaikuttavuus näyttää olevan suurinta alemmissa sosioekonomisissa ryhmissä. Veron tason on kuitenkin syytä olla tuntuva ja ohjaustoimet olisi syytä suunnitella niin, että saatavissa on sopivia korvaavia tuotteitta. Esimerkiksi virvoitusjuomaveron kohdentaminen sokeripitoisiin tuotteisiin on toiminut hyvin, koska se on siirtänyt kulutusta sokeripitoisista juomista sokerittomiin.

\section{RUOKAYMPÄRISTÖN MUOKKAAMINEN}

Suuri osa arkisista ruokavalinnoista on tiedostamattomia. Syömme sitä, mitä on helposti saatavilla ja mitä olemme tottuneet syömään. Ruokaympäristön muokkaamisen avulla ihmisiä voidaan tuupata kohti terveellisempiä ja ilmastoystävällisempiä valintoja. Pienempi lautanen linjastossa vähentää ruokamäärää ja hävikkiä, kasvisten houkutteleva esillepano ennen pääruokaa voi vähentää liharuoan annoskokoa. Kuluttajien tuuppaaminen terveellisempiin valintoihin toimii erityisesti silloin, kun se ei joudu kilpailemaan vastakkaisten kaupallisten viestien kanssa ja kun tuuppaaminen täydentää muita ohjausmenetelmiä kuten lainsäädäntöä ja fiskaalisia toimia. (24) Kulutuksen ohjaaminen toimii parhaiten silloin, kun käyttäytymistä ei tarvitse suuresti muuttaa, muutoksen hyödyt ovat kuluttajille ymmärrettäviä ja muu ympäristö tukee tai seuraa mukana (4). Yhteisten tavoitteiden ymmärtäminen ja ruokajärjestelmän kaupallisten toimijoiden mukaan saaminen suositusten toimeenpanoon on ruokaympäristön muuttamisen kannalta keskeisen tärkeää $(6,23)$.

Ruokaympäristöön vaikuttaminen on moniulotteinen prosessi. Siinä on mukana yhteiskunnan terveyden edistämisen ja ilmastonmuutoksen torjunnan tavoitteiden lisäksi monenlaisia muita intressejä ja monia toimijoita. Suomessa ruokaympäristön muokkaamiseen tukena on 2017 lanseerattu Ravitsemussitoumus toimintamalli osana kestävän kehityksen yhteiskuntasitoumusta. Toimintamalli kannustaa yrityksiä, ruokapalveluja, järjestöjä ja muita toimijoita tekemään sitoumuksia esimerkiksi kasvisten käytön lisäämiseksi, aterioiden ja elintarvikkeiden laadun parantamiseksi, annos- ja pakkauskokojen pienentämiseksi ja terveellisempiin ruokaohjeisiin (25). Vapaaehtoisten toimien riittävyys on kuitenkin kyseenalaistettu. Kaupalliset intressit voivat monissa yrityksissä olla esteenä terveysja ympäristötavoitteiden edistämiselle, jolloin vapaaehtoisuuteen perustuvat toimet ruokaympäristön muuttamiseksi eivät välttämättä saa aikaan merkittäviä muutoksia. Velvoittavammat toimet kuten lainsäädäntö, normit ja fiskaalinen ohjaus ovat usein tehokkain tapa edistää muutosta mutta voivat olla poliittisesti vaikeampia toteuttaa (3). Julkinen ohjaus voi tukea ruokajärjestelmän muutosta vahvoilla strategisilla tavoitteilla ja säädöksillä sekä taloudellisten ja tiedollisten ohjauskeinojen yhdistelmällä (14).

\section{KOULUTUS, KASVATUS JA VIESTINTÄ}

Terveyttä ja ympäristöä tukeva ruokavalio vaatii tuekseen monenlaisia tietoja ja taitoja sekä niitä tukevaa koulutusta, kasvatusta ja viestintää. Kuluttajat ovat usein kiinnostuneita terveyden ja ympäristötavoitteiden edistämisestä mutta eivät tiedä miten tulisi toimia (26). Erityisesti ympäristöosaamisen kohdalla on myös paljon tietovajetta. Esimerkiksi tuotteiden pakkausten tai elintarvikekuljetusten haitallisuutta ylikorostetaan tai luomutuotantoon liitetään katteettomia mielikuvia terveydestä ja ilmastohyödyistä (3).

Tiedotuskampanjoilla voidaan pyrkiä vaikuttamaan kuluttajan tietopohjaan mutta niiden 
vaikuttavuudesta on vain rajallisesti näyttöä (14) eivätkä ne yksin riitä muuttamaan toimintaa, jos ruokaympäristö ei samalla muutu $(2,3,13,27)$. Ostotilanteessa voidaan kuluttajalle viestiä tietoa tuotteiden laadusta pakkausmerkintöjen avulla, mutta myös näyttö erilaisten ympäristöystävällisyyttä kuvaavien merkintöjen vaikuttavuudesta vaihtelee. Merkintöjä ymmärtävät parhaiten hyvin koulutetut ja asiasta valmiiksi kiinnostuneet. Toisaalta merkinnät voivat lisätä yleistä tietoisuutta ilmastovaikutusten tai muiden kestävyysaspektien huomioimisen tärkeydestä myös niissä kuluttajaryhmissä, joissa tietoisuus on vähäisempää (27).

Suomessa ruokaan liittyvän osaamisen ja kasvatuksen pohja rakentuu pitkälti koulutusjärjestelmässämme. Uusiin esi- ja perusopetussuunnitelman perusteisiin ruokakasvatus on kirjattu aikaisempaa kattavammin. Ruokapoliittinen selonteko esittää muun muassa sekä ravitsemusettä kestävyysnäkökulman vahvistamista varhaiskasvatuksessa, peruskoulussa, toisen asteen koulutuksessa ja opettajakoulutuksessa (6). Lisäksi hallitusohjelma lupaa, että ilmasto- ja ympäristöystävälliseen ruokajärjestelmään liittyvään koulutukseen ja neuvontaan panostetaan, laaditaan kouluruoan kehittämisohjelma sekä kehitetään terveellistä, yhteisöllistä ja ekologista kouluruokailua (13).

\section{YHTEISTYÖLLÄ ETEENPÄIN}

Ruokajärjestelmän muuttaminen terveyttä ja kestävyyttä edistävään suuntaan tulee lähitulevaisuudessa vaatimaan poliittista johtajuutta, vahvaa yhteistyötä sekä sitoutumista yli sektoreiden ja hallintorajojen kaikilla tasoilla ja monilla eri toimenpiteillä. EAT-Lancet komission arvion mu- kaan mitkään yksittäiset toimet eivät ole riittäviä ilmastomuutoksen torjuntaan. Tarvitaan mittava rakenteiden ja toiminnan muutos, joka vaatii sekä tiukkoja pakottavia säädöksiä että vapaaehtoisia toimia koko ruokajärjestelmässä (2).

Meillä Suomessa myös pohjoismainen yhteistyö muodostaa hyvän pohjan terveellisen ja kestävän ruokavalion vahvistamiselle. Pohjoismainen asiantuntijatyö ravitsemussuositusten uudistamiseksi on jo alkanut. Terveellisen ja kestävän ruokavalion merkitystä suosituksissa voisi vahvistaa esimerkiksi ottamalla mukaan konkreettisia päästötavoitteita tai suosituksia julkisista hankinnoista. Yhteistyötä voisi tehdä nykyistä enemmän myös esimerkiksi ruokavalioiden ja niiden ympäristövaikutusten arvioinnissa, epäterveellisten elintarvikkeiden markkinoinnin rajoittamisessa, lainsäädännön kehittämisessä ja tuotannon suuntaamisessa kohti terveellisempää ja kestävämpää ruokajärjestelmää. (12)

Haasteet ja paineet ruokajärjestelmän muuttamiselle kohti kestävää ja terveellistä tarjontaa ovat suuret $(2-4,5,11,14)$. Hallitusohjelma on nostanut lähivuosien suuntaviivoja muutokselle (13). Niiden toimeenpaneminen tulee vaatimaan yhteistyön tiivistämistä ja monia erilaisia poikkihallinnollisia toimia eri sektoreilla sekä eri hallinnon tasoilla. Mukaan tulee saada Suomessa hallituksen eri ministeriöiden lisäksi myös esimerkiksi kunnat, joilla on vastuu monista käytännön ratkaisuista liittyen esimerkiksi julkisten ruokapalvelujen tarjontaan, ruokaympäristöön ja opetuksen järjestämiseen.

\section{RAHOITTAJAT:}

Tutkimusta on rahoittanut Tiina ja Antti Herlinin säätiö.

\section{Sarlio, S. Promoting health and sustainability by food and nutrition policies. Sosiaalilääketieteellinen}

aikakauslehti- Journal of Social Medicine 2019: 56: 31 8-326.

Dietary habits play a crucial role in promoting health and combatting climate change. Sustainability and health are part of Finnish and Nordic nutrition recommendations but inadequately implemented. Current problems include excessive intake of energy and red meat whereas intake of vegetables, fruits and berries is too low. Nutrition and food policy should pay attention to human health and food systems but also environmental health and planetary boundaries. Sustainable and healthy dietary habits can be promoted by influencing agricultural policies, using fiscal tools, public procurement and food services, education and information, research and innovation as well as influencing food environment. Transforming food systems towards sustainable development 
requires many different cross-sectoral measures. In addition to government action, municipalities need to be involved as they are responsible for many practical measures concerning food environment, public food services and education.

Keywords: nutrition, sustainability, climate change, policy, public health

Saapunut 27.06.2019

Hyväksytty 18.10.2019

\section{LÄHTEET}

1. Intergovernmental Panel on Climate Change. Climate Change and Land. An IPCC Special Report on climate change, desertification, land degradation, sustainable land management, food security and greenhouse gas fluxes in terrestrial ecosystems. 2019.

2. Willet W, Rockström J, Loken B, ym. Food in the Anthropocene: the EAT-Lancet Commission on healthy diets from sustainable food systems. Lancet 2019;393;447-92. https://doi.org/10.1016/S0140-6736(18)31788-4

3. Sarlio $S$. Towards healthy and sustainable diets. Perspectives and policy to promote the health of the people and the planet. Cham: Springer 2018. https://doi.org/10.1007/978-3-319-74204-5

4. Terveyttä Ruoasta. Suomalaiset ravitsemussuositukset 2014. Valtion ravitsemusneuvottelukunta. Helsinki 2014.

5. Maatalouden ilmasto-ohjelma -askeleita kohti ilmastoystävällistä ruokaa. Maa- ja metsätalousministeriö 8/2014.

6. Valtioneuvoston selonteko ruokapolitiikasta Ruoka 2030. Suomi-ruokaa meille ja maailmalle. Maa- ja metsätalousmnisteriö 2017.

7. Clune S, Crossin E, Verghese K. Systematic review of greenhouse gas emissions from different fresh food categories. J Clean Prod 2016;140(2):766783. https://doi.org/10.1016/j.jclepro.2016.04.082

8. Hartikainen H, Pulkkinen P (2016) Summary of the chosen methodologies and practices to produce GHE-estimates for an average European diet. Natural resources and bioeconomy studies 57/2016. Luke natural resources Institute, Finland.

9. Ausley E, Brander M, Chatterton J, ym. How low can we go? An assessment of greenhouse gas emissions from UK food system and the scope to reduce them by 2050. FCRN-WWF-UK.

10. Valsta L, Kaartinen N, Tapanainen H ym. Ravitsemus Suomessa -Finravinto 2017 -tutkimus. Terveyden ja Hyvinvoinnin laitos 12/2018. Helsinki: Punamusta 2018.

11. Mäki P, Harard K, Linström J, Laatikainen T. Ylipainoon ja lihavuuteen liittyvä sairastavuus. Tutkimuksesta tiiviisti 14/2019. Terveyden ja hyvinvoinnin laitos 2019.
12. Woods A, Gordon LJ, Röös E ym. Nordic food systems for improved health and sustainability. Baseline assessment to inform transformation. Stockholm Resilience Centre Report 2019.

13. Neuvottelutulos hallitusohjelmasta 3.6.2019. Osallistava ja osaava Suomi - sosiaalisesti, taloudellisesti ja ekologisesti kestävä yhteiskunta. Helsinki 2019.

14. Saarinen M, Kaljonen M, Niemi J ym. Ruokavaliomuutoksen vaikutukset ja muutosta tukevat politiikkayhdistelmät. RuokaMinimi -hankkeen loppuraportti. Valtioneuvoston selvitysja tutkimustoiminnan julkaisusarja 2019:47, 2019.

15. EPHA European Public Health Alliance. Mainstreaming health into the EU Common Agricultural Policy. AISBL 2016.

16. Snowdon W, Potter J-L, Swinburn B, Schultz J. Prioritizing policy interventions to improve diets? Will it work, can it happen, will it do harm? Health Promot Int 2010:25(1):123-133. https://doi.org/10.1093/heapro/daq003

17. Report from the Commission to the Council and the European Parliament on the development of plant proteins in the European Union. Brussels 22.22.2018. COM (2018) 757 Final. European Commission.

18. Valtioneuvoston periaatepäätös julkisten elintarvike- ja ruokapalveluhankintojen arviointiperusteista (ympäristömyönteiset viljelytavat, elintarviketurvallisuutta ja eläinten hyvinvointia edistävät tuotanto-olosuhteet). VNPP 29.6.2016.

19. Opas vastuullisiin elintarvikehankintoihin. Suosituksia vaatimuksiksi ja vertailukriteereiksi. 3/2017. Motivan hankintapalvelu 2017.

20. Neto B, Rodriquez Q, Wolf O ym. Revision of the EU green public procurement criteria for food and catering services, JCR Science and Policy Report, JCR, Sevilla 2016.

21. Niebylski ML, Lu T, Cambell NR ym. Healthy food procurement policies and their impact. Int J Environ Res Public Health 2014:11:2608-2627. https://doi.org/10.3390/ijerph110302608

22. Springmann M, Mason-D'Croz, Robinson ym. Mitigation potential and global health impacts from emission procing of food commodities. Nat Clin Chang 2016:7:69-74. https://doi.org/10.1038/nclimate3155

23. Erkkola M, Fogelholm M, Konttinen H, ym. Ruokaympäristön osatekijät ja ohjauskeinot. Valtioneuvoston selvitys- ja tutkimustoiminnan julkaisusarja 2019:51, 2019.

24. Lehner M, Mont O, Heiskanen E. Nudging -a promising tool for sustainable consumption behaviour? J Clean Prod 2016:134:166-177. https://doi.org/10.1016/j.jclepro.2015.11.086

25. Sarlio S, Lyytikäinen A, Raulio S, Virtanen S. Kohti terveellistä ja kestävää ruokavaliota: Ravitsemussitoumusjärjestelmä haastaa parantamaan ruoan laatua ja edistämään vastuullisia toimintatapoja. Lääketieteellinen Aikakauskirja Duodecim (painossa). 
26. Gjerris M, Camborg C, Saxe H. What to buy? On the complexity of being a critical consumer. J Agric Environ Ethics 2016:29:81-102.

https://doi.org/10.1007/s10806-015-9591-6

27. Ihemezie EJ, Ukwuaba IC, Nnaji AP. Impact

of "green" product label standards on consumer

behaviour: A systematic review analysis. Int J

Academic Research in Business and Social Sciences 2018:8(9):666-684.

https://doi.org/10.6007/IJARBSS/v8-i9/4647

\section{Sirpa SARLio}

FT, VTM, ETM, dosentti, neuvotteleva virkamies Helsingin yliopisto, maatalous-metsätieteellinen tiedekunta

Sosiaali- ja terveysministeriö, Hyvinvointi- ja palvelut osasto 